\title{
Online Appendix
}

"Life-Cycle Consumption Patterns at Older Ages in the US and the UK:

Can Medical Expenditures Explain the Difference?"

\author{
James Banks, Richard Blundell, Peter Levell, and James P. Smith
}

\section{Appendix A: Long Term Care Costs}

Table A1: Distribution of Out-of-pocket Long-Term Care Costs, Non-institutional Population

\begin{tabular}{lccccccc}
\hline HRS: United States & percent & Mean & P25 & P50 & P75 & P95 & P99 \\
All household population 60+ & 100 & 53 & 0 & 0 & 0 & 0 & 526 \\
Any stays in institutions (past 2 yrs) & 5.3 & 991 & 0 & 0 & 246 & 3768 & 29075 \\
Any paid-for stays in institutions (past 2 yrs) & 1.7 & 3085 & 263 & 645 & 2010 & 12975 & 38189 \\
ELSA: England & & & & & & & \\
All household population 60+ & 100 & 30 & 0 & 0 & 0 & 0 & 0 \\
Any stays in institutions (past 2 yrs) & 1.1 & 3236 & 0 & 0 & 1257 & 15699 & 37704 \\
Any paid-for stays in institutions (past 2 yrs) & 0.6 & 6619 & 628 & 1782 & 10055 & 28278 & 37704 \\
\hline
\end{tabular}

Note: Data from English Longitudinal Study of Ageing for England and the Health and Retirement Survey in the US for those not in institutional residences at the time of interview. Values are annual averages over the previous two years in US\$ (2010). US spending is for 2012-2014. UK spending is for 2014-2016. 


\section{Appendix B: Within Period Demand Systems}

\section{A. A Model for Demand}

In this appendix, we estimate an extension of the Almost Ideal specification of Deaton and Muellbauer (1980) that includes an additional quadratic term in income (Banks et al. 1997). Our interest is in establishing the nature of within-period non-separabilities between consumption and housing, health and employment in the two countries through the effect of these variables on household budget shares. By including total expenditure and prices, we control for differences in trends in relative prices and wealth across different birth cohorts in the two countries, which may otherwise confound our estimates.

We run the following consumer demand model in each of the two countries:

$$
w_{i k}=\alpha_{i k}+\sum_{k}^{G} \gamma_{k} \ln p_{k}+\beta_{k} \ln \left\{\frac{x_{i}}{a_{i}(p)}\right\}+\theta_{k} \ln \left\{\frac{x_{i}}{a_{i}(p)}\right\}^{2}
$$

where $w_{\mathrm{ik}}$ is the budget share of individual $i$ for each of the $G$ goods $k, p_{k}$ is the price of good $k$ and $x_{i}$ is total expenditure on the goods included in the demands system by individual $i$. There are $M$ demographic variables $z_{m i}$ for each individual $i$ including housing, employment, health and mortality are included in $\alpha_{i k}$

$$
\alpha_{i k}=\alpha_{k 0}+\sum_{k}^{M} \alpha_{m k} z_{m i}
$$

Expenditures are deflated using the price index

$$
\ln a_{i}(p)=\alpha_{O}+\sum_{k}^{G} \alpha_{i k} \ln p_{k}+\frac{1}{2} \sum_{l}^{G} \sum_{k}^{G} \gamma_{l k} \ln p_{l} \ln p_{k}
$$

This model differs slightly from the Almost Ideal specification of Deaton and Muellbauer (1980) in that it includes an additional quadratic term on income (although it is still only an approximation to the fully integrable QUAIDS model (Banks et al. 1997)). Our interest is in establishing the nature of within-period non-separabilities between consumption and housing, health and employment in the two countries through the effect of these variables on household budget shares. By including total expenditure and prices, we control for differences in trends in relative prices and wealth across different birth cohorts in the two 
countries which may otherwise confound our estimates. The use of the household specific price index $a_{i}(p)$ means that income deflators can vary across groups according to their differing consumption patterns.

Prices for each of our categories are computed from the individual components and sub-indices of the UK Retail Prices Index and the US CPI, which go back to 1978 and 1988 respectively. ${ }^{1}$ Typically, sub-indices are not available for the particular category grouping we use (defined in Table 1). For instance, in the UK RPI medical costs are split between "personal services," "chemists goods," "personal articles" and other categories. So in order to calculate price indices for these goods we calculate a Stone price index for a given category $k$

$$
p_{k}=\exp \left(\sum_{j=1}^{G_{k}} w_{j k} \log p_{j}\right)
$$

where $w_{j k}$ is the cohort-year budget share of good $j$ within some spending category $k$ for which there are $G_{k}$ goods in category $k$ for which we want a price (e.g. "other nondurables"). We plot the estimated series for medical costs in Figure A.1. This shows that real medical prices tended to increase faster in the US than they did in the UK over the period we are considering. This implies that the growth in medical consumption in the US may not have been as large relative to the UK as the growth in medical expenditures.

\footnotetext{
${ }^{1}$ The authors are grateful to Brendan Williams of BLS for constructing price indices that go back to this date.
} 


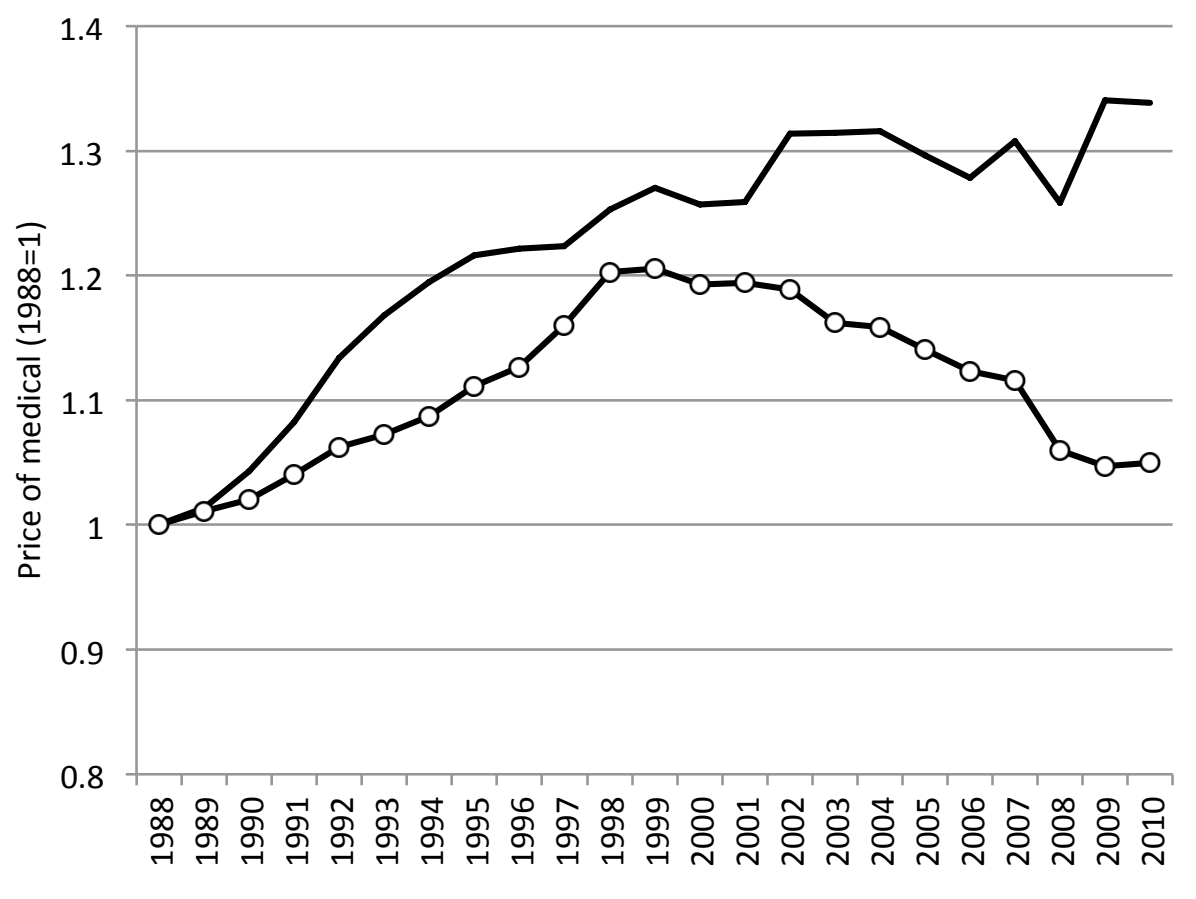

$\longrightarrow$ US $\rightarrow$ UK

\section{Figure B.1. Real Price of Medical Spending}

Note: UK prices are a weighted geometric mean of the RPI categories that include medical spending. US prices are a weighted geometric mean of prices for medical care and hospital services. In both calculations the weights are shares of total medical expenditure. Prices are made real with a Stone price index for total nondurable spending.

Our demand system includes sex, number of children, number of adults, and linear and quadratic time trends as controls in all models reported below. We also include dummies for being over state pension age in the UK (60 for women, 65 for men) and for being over 65 in the US. These are included to control for the effects of Medicare (to which US households become eligible at 65) and benefits such as free-prescriptions, the Winter Fuel Payment, and transport subsidies which UK households become eligible for at state pension age. We do not otherwise control for age - our view is that age is usually included as a proxy for health and mortality effects, and these are affects that we are directly interested in (and include separately). The health and mortality variables are cell averages for the population (by age, year and sex) based on the data we described in Section IV above. We instrument the expenditure and expenditure squared variables using income and income squared (dummying out changes in the income question in the CEX that occurred from the $2^{\text {nd }}$ quarter of $2001-$ introducing a bracketing question for those who failed to report their incomes - and income imputation which was introduced in 2004). 
Table B.1 Estimated Demand System Coefficients $\alpha_{m k}$

\begin{tabular}{|c|c|c|c|c|c|c|c|}
\hline & Food in & Food out & OthND & Medical & Housing & Recrea & Transport \\
\hline \multicolumn{3}{|c|}{ Mean Budget Shares (percent): } & \multicolumn{3}{|c|}{ UK (1978-2010) } & & \\
\hline & 24.36 & 4.97 & 25.10 & 1.88 & 23.82 & 7.29 & 12.58 \\
\hline \multirow[t]{2}{*}{ Single } & -6.63 & 2.62 & 3.34 & -0.26 & -2.39 & -0.08 & 3.40 \\
\hline & $(0.12)$ & $(0.07)$ & $(0.16)$ & $(0.06)$ & $(0.14)$ & $(0.15)$ & $(0.13)$ \\
\hline \multirow[t]{2}{*}{ Renter } & 0.85 & 0.38 & 3.26 & 0.01 & -4.17 & 0.43 & -0.77 \\
\hline & $(0.09)$ & $(0.05)$ & $(0.12)$ & $(0.05)$ & $(0.11)$ & $(0.11)$ & $(0.10)$ \\
\hline \multirow[t]{2}{*}{ Own-outright } & 0.14 & -0.11 & -0.75 & 0.16 & -0.04 & 0.92 & -0.31 \\
\hline & $(0.08)$ & $(0.05)$ & $(0.11)$ & $(0.04)$ & $(0.10)$ & $(0.10)$ & $(0.09)$ \\
\hline \multirow[t]{2}{*}{ Head-employed } & -0.03 & 0.61 & -0.42 & -0.05 & -0.81 & -0.40 & 1.11 \\
\hline & $(0.09)$ & $(0.05)$ & $(0.12)$ & $(0.05)$ & $(0.10)$ & $(0.11)$ & $(0.10)$ \\
\hline \multirow[t]{2}{*}{ Both work } & -0.67 & 0.23 & 0.71 & -0.14 & -0.47 & 0.43 & -0.10 \\
\hline & $(0.09)$ & $(0.06)$ & $(0.13)$ & $(0.05)$ & $(0.11)$ & $(0.12)$ & $(0.11)$ \\
\hline \multirow[t]{2}{*}{$\ln$ (mortality) } & 0.85 & -0.00 & -1.81 & 0.36 & 0.78 & 0.17 & -0.35 \\
\hline & $(0.06)$ & $(0.04)$ & $(0.09)$ & $(0.04)$ & $(0.07)$ & $(0.08)$ & $(0.07)$ \\
\hline Worst health & $\begin{array}{l}\mathbf{- 0 . 5 3} \\
(0.46)\end{array}$ & $\begin{array}{c}\mathbf{- 0 . 2 9} \\
(0.28)\end{array}$ & $\begin{array}{c}\mathbf{- 0 . 1 6} \\
(0.63)\end{array}$ & $\begin{array}{c}\mathbf{0 . 2 8} \\
(0.26)\end{array}$ & $\begin{array}{l}\mathbf{- 1 . 1 2} \\
(0.55)\end{array}$ & $\begin{array}{c}\mathbf{0 . 9 8} \\
(0.55)\end{array}$ & $\begin{array}{c}\mathbf{0 . 8 4} \\
(0.48)\end{array}$ \\
\hline \multicolumn{3}{|c|}{ Mean Budget Shares (percent): } & \multicolumn{3}{|c|}{ US (1988-2010) } & & \\
\hline & 22.00 & 6.50 & 17.82 & 12.61 & 19.99 & 4.26 & 16.81 \\
\hline \multirow[t]{2}{*}{ Single } & -4.74 & 3.02 & 2.17 & -3.57 & -0.54 & 1.33 & 2.34 \\
\hline & $(0.24)$ & $(0.15)$ & $(0.24)$ & $(0.35)$ & $(0.24)$ & $(0.13)$ & $(0.22)$ \\
\hline \multirow[t]{2}{*}{ Renter } & -0.28 & 2.14 & 4.86 & 0.83 & -10.32 & 1.45 & 1.34 \\
\hline & $(0.26)$ & $(0.17)$ & $(0.26)$ & $(0.37)$ & $(0.26)$ & $(0.14)$ & $(0.24)$ \\
\hline \multirow[t]{2}{*}{ Own-outright } & 0.08 & 0.53 & -0.71 & 0.57 & -0.33 & 0.09 & -0.25 \\
\hline & $(0.13)$ & $(0.08)$ & $(0.13)$ & $(0.20)$ & $(0.13)$ & $(0.07)$ & $(0.12)$ \\
\hline \multirow[t]{2}{*}{ Head-empl. } & 0.96 & 0.46 & -0.60 & -1.68 & 0.10 & -0.32 & 1.05 \\
\hline & $(0.18)$ & $(0.11)$ & $(0.18)$ & $(0.26)$ & $(0.18)$ & $(0.09)$ & $(0.16)$ \\
\hline \multirow[t]{2}{*}{ Both work } & -2.18 & 0.45 & 1.33 & -0.09 & -0.90 & 0.31 & 1.09 \\
\hline & $(0.18)$ & $(0.11)$ & $(0.18)$ & $(0.26)$ & $(0.18)$ & $(0.09)$ & $(0.17)$ \\
\hline \multirow[t]{2}{*}{$\ln$ (mortality) } & -0.53 & -0.45 & -1.80 & 2.72 & 0.99 & -0.12 & -0.81 \\
\hline & $(0.14)$ & $(0.08)$ & $(0.13)$ & $(0.20)$ & $(0.14)$ & $(0.07)$ & $(0.12)$ \\
\hline \multirow[t]{2}{*}{ Worst health } & -0.19 & -0.30 & 2.28 & -0.30 & -1.90 & -0.89 & 1.32 \\
\hline & $(0.65)$ & $(0.39)$ & $(0.63)$ & $(0.94)$ & $(0.63)$ & $(0.33)$ & $(0.58)$ \\
\hline \multicolumn{8}{|c|}{$\begin{array}{l}\text { UK N=99,425; US N= 50,796, standard errors in parentheses. We take only data from the first interview in the } \\
\text { CEX. Additional controls for log expenditure, log expenditure squared, number of children, number of adults, } \\
\text { dummy for whether head or spouse has compulsory education, a quadratic time trend, being over state pension } \\
\text { age and self-reported health missing. Expenditure is instrumented using income (with additional dummies in } \\
\text { US model for year greater than } 2001 \text { and year greater than } 2004 \text {, when changes to the survey income questions } \\
\text { were introduced). }\end{array}$} \\
\hline
\end{tabular}

The coefficients on the taste shifters, $\alpha_{m k}$ are shown in Table B.1. The particular specification of the demographic variables, $z$, includes: (1) housing tenure with dummy variables for being a renter and housing owners with no mortgage so that the reference group 
are owners with remaining mortgages; (2) marital status represented a dummy variables for being single; (3) employment proxied by two dummies-household head employed and both partners working; (4) the log of mortality of the head (5) the health of head captured by the proportion of individuals in their cohort who have the worst health status.

In both countries, the demand system results show that those who rent not surprisingly spend a much smaller share of the budget on housing related expenditures. In the US the share spent on housing related expenses is 10 percentage points lower for renters than those who own. In the UK the equivalent number is 4 percentage points. The estimates in Table B1 of Appendix B indicate renters consequently devote higher shares to all other goods (except food at home in the US), with a particularly large effect for other nondurable spending. Owning a home outright (compared to owners who still have a mortgage to pay off) leads to small reduction in housing related expenses in both countries (though the effect is not significant in the UK).

Employment effects look as expected - in both countries when the head is employed less is spent on recreation and more is spent on food out and on transport, which is most likely associated with transport to work. Employment in the United States is associated with more food consumption both in and out of the home, but in the UK there is a substitution of food consumption to out of the home. When both head and spouse are working, there is a reduction in spending on food at home in the US.

Important differences emerge in the relationship between employment and health costs, however. In the United States where people bear more of the responsibility for paying their medical costs, the head's employment reduces out-of-pocket medical expenses, a much larger effect than in the UK where the effect is essentially zero. Although this could partly be explained by incomplete controls for health in the model, the key difference is the association between medical insurance and being in a job in the United States (as reflected in Figure 7). In the US, the head being employed reduces the proportion spent on medical spending by 1.7 percentage points but there is no similar effect in the UK. This could reflect employers meeting some healthcare costs for their employees in the US (which in the UK would be met by the state). Whether the spouse works or not, does not appear to contribute to this effect. ${ }^{2}$

\footnotetext{
${ }^{2}$ When we exclude health insurance spending from medical expenditures the estimated impact of employment on the share of spending on medical in the US goes from -1.7 to -0.9 . The value of this coefficient may seem surprising given discounts for employer-sponsored insurance, However, those leaving employment may still be covered by third parties as Figure 7 suggests (e.g. through retiree benefit plans).
} 
Due to the data limitations described above, our mortality and subjective health measures capture variations in health status that occur on average at the cohort level rather than individual level variation. A higher risk of mortality among the cohort increases medical spending in both the US and UK with, perhaps unsurprisingly in light of the differential financing of medical care in the two countries, a much larger effect in the US. In the UK, reductions in subjective health controlling for mortality have little effect on the composition of total household consumption (except for a reduction in spending away from home). In contrast, a worsening of the cohort's subjective health status in the United States leads to an apparent (but statistically insignificant) reduction in medical expenses once the effects of mortality are controlled. This likely reflects some difference in health spending among cohorts that we have not been able to control for (for instance, those caused by institutional changes in Medicare coverage or changes in the availability of expensive, technologyintensive health services over time).

Comparing the positive impact of mortality probabilities on medical spending with the zero or negative effects for self-reported health suggests that subjective measures of health may not improve even when objective measures of health do. One possible explanation for this is that people assess their health relative to others in their cohort (so self-reported health status would tend to vary within but not between cohorts), weakening its association with actual health conditions and so medical expenditures.

In Table B. 2 we show coefficients from demand system excluding medical spending, additionally controlling for the quantity of medical consumption (defined as the volume of medical spending or expenditure divided by price). This is a model of conditional demands (using the language of Pollak 1969), allowing us to test for the presence of non-separabilties in medical consumption over and above those associated with ill-health. In both countries, much medical consumption is publicly provided and can only be obtained in rationed quantities. As a result, we instrument medical consumption with its price. To make our results easier to interpret, we also scale medical expenses by their standard deviation in both countries. We use a test of the significance of the medical quantity term to test the hypothesis of separability between medical and other demands. In both countries, we find evidence of non-separability. In the US, higher medical quantities are associated with significantly lower spending on other nondurables and recreation. Our results imply a one standard deviation increase in medical quantities in the US is associated with an increase in the US budget share on housing related goods by around 7 percentage points. The direction of effects for the UK are similar to those for the US, except that higher medical consumption in the UK is 
associated with lower (rather than higher) spending on housing and with higher (rather than lower) recreation spending. However, the latter of these effects is not significant in the UK. 
Table B.2 Estimated Conditional Demand System Coefficients $\alpha_{m k}$ (No

Medical)

\begin{tabular}{|c|c|c|c|c|c|c|}
\hline & Food in & Food out & OthND & Housing & Recrea & Transport \\
\hline \multirow{2}{*}{$\begin{array}{l}\text { Mean Budget Shares } \\
\text { (percent) }\end{array}$} & \multicolumn{6}{|c|}{ UK (1978-2010) } \\
\hline & 24.81 & 5.07 & 25.55 & 24.29 & 7.44 & 12.83 \\
\hline \multirow[t]{2}{*}{ Single } & -8.50 & 6.71 & 1.21 & -3.37 & 0.01 & 3.79 \\
\hline & $(0.41)$ & $(0.68)$ & $(0.51)$ & $(0.37)$ & $(0.23)$ & $(0.21)$ \\
\hline \multirow[t]{2}{*}{ Renter } & 1.45 & -0.89 & 3.91 & -3.89 & 0.36 & -0.88 \\
\hline & $(0.22)$ & $(0.34)$ & $(0.28)$ & $(0.15)$ & $(0.13)$ & $(0.12)$ \\
\hline \multirow[t]{2}{*}{ Own-outright } & 1.09 & -2.09 & 0.25 & 0.50 & 0.84 & -0.51 \\
\hline & $(0.24)$ & $(0.38)$ & $(0.30)$ & $(0.19)$ & $(0.13)$ & $(0.13)$ \\
\hline \multirow[t]{2}{*}{ Head-employed } & -0.08 & 0.74 & -0.49 & -0.89 & -0.39 & 1.10 \\
\hline & $(0.19)$ & $(0.28)$ & $(0.25)$ & $(0.11)$ & $(0.11)$ & $(0.11)$ \\
\hline \multirow[t]{2}{*}{ Both work } & -2.11 & 3.41 & -0.88 & -1.31 & 0.57 & 0.21 \\
\hline & $(0.32)$ & $(0.54)$ & $(0.41)$ & $(0.29)$ & $(0.18)$ & $(0.17)$ \\
\hline \multirow[t]{2}{*}{$\ln$ (mortality) } & 2.30 & -2.99 & -0.08 & 1.51 & 0.01 & -0.64 \\
\hline & $(0.30)$ & $(0.50)$ & $(0.37)$ & $(0.28)$ & $(0.17)$ & $(0.15)$ \\
\hline \multirow[t]{2}{*}{ Worst health } & -0.68 & -0.23 & -1.27 & -0.64 & 1.46 & 1.36 \\
\hline & $(1.07)$ & $(1.55)$ & $(1.40)$ & $(0.61)$ & $(0.62)$ & $(0.62)$ \\
\hline \multirow[t]{2}{*}{ Medical quantity } & -24.66 & 59.62 & -30.00 & -14.94 & 1.66 & 5.98 \\
\hline & $(4.73)$ & $(8.44)$ & $(5.71)$ & $(5.09)$ & $(2.52)$ & $(2.16)$ \\
\hline \multirow{2}{*}{$\begin{array}{l}\text { Mean Budget Shares } \\
\text { (percent) }\end{array}$} & \multicolumn{6}{|c|}{ US (1988-2010) } \\
\hline & 25.28 & 7.38 & 20.31 & 23.07 & 4.80 & 19.15 \\
\hline \multirow[t]{2}{*}{ Single } & -6.33 & 3.12 & 0.68 & 0.38 & -0.41 & 2.50 \\
\hline & $(0.52)$ & $(0.31)$ & $(0.42)$ & $(0.47)$ & $(0.30)$ & $(0.38)$ \\
\hline \multirow[t]{2}{*}{ Renter } & 0.10 & 2.46 & 5.66 & -11.75 & 1.67 & 1.91 \\
\hline & $(0.30)$ & $(0.19)$ & $(0.27)$ & $(0.31)$ & $(0.19)$ & $(0.27)$ \\
\hline \multirow[t]{2}{*}{ Own-outright } & 0.18 & 0.65 & -0.51 & -0.55 & 0.54 & -0.30 \\
\hline & $(0.18)$ & $(0.11)$ & $(0.15)$ & $(0.18)$ & $(0.11)$ & $(0.15)$ \\
\hline \multirow[t]{2}{*}{ Head-employed } & 0.60 & 0.41 & -1.31 & 0.17 & -0.67 & 0.76 \\
\hline & $(0.22)$ & $(0.14)$ & $(0.20)$ & $(0.23)$ & $(0.14)$ & $(0.19)$ \\
\hline \multirow[t]{2}{*}{ Both work } & -2.78 & 0.57 & 1.30 & -0.35 & -0.39 & 1.64 \\
\hline & $(0.29)$ & $(0.17)$ & $(0.24)$ & $(0.28)$ & $(0.17)$ & $(0.23)$ \\
\hline \multirow[t]{2}{*}{$\ln$ (mortality) } & 0.13 & -0.34 & -0.62 & 0.42 & 1.03 & -0.56 \\
\hline & $(0.34)$ & $(0.21)$ & $(0.27)$ & $(0.30)$ & $(0.21)$ & $(0.23)$ \\
\hline \multirow[t]{2}{*}{ Worst health } & -0.43 & -0.23 & 2.23 & -1.79 & -1.61 & 1.84 \\
\hline & $(0.71)$ & $(0.43)$ & $(0.66)$ & $(0.77)$ & $(0.45)$ & $(0.66)$ \\
\hline \multirow[t]{2}{*}{ Medical quantity } & -2.18 & 1.10 & -2.99 & 6.98 & -5.28 & 2.03 \\
\hline & $(1.75)$ & $(1.08)$ & $(1.31)$ & $(1.47)$ & $(1.04)$ & $(1.08)$ \\
\hline
\end{tabular}

$\mathrm{UK} \mathrm{N}=99,425$; US N=50,796, standard errors in parentheses. We take only data from the first interview in the CEX. Additional controls for log expenditure, log expenditure squared, number of children, number of adults, dummy for whether head or spouse has compulsory education, a quadratic time trend, being over state pension age and self-reported health missing. Expenditure is instrumented using income (with additional dummies in US model for year greater than 2001 and year greater than 2004, when changes to the survey income questions were introduced). Medical quantity is instrumented with its log price and scaled by its standard deviation in both countries. 


\section{Appendix C: Life-Cycle Profile of Expenditures}

In this appendix, we consider how life-cycle profiles of spending vary across different spending categories in the two countries. Figures $\mathrm{C} 1$ and $\mathrm{C} 2$ show average spending on the eight different expenditure categories listed in Table 1 for those born in a particular cohort (those born in the years 1933-1937). We observe this cohort for almost our entire sample period, making it particular informative to look at. We observe similar patterns, for the portions of their later life that are covered by our data, when considering alternative cohorts.

Figure $\mathrm{C} 1$ shows spending in the UK. Average spending falls from around $\$ 700$ per week at age 48 to just under $\$ 400$ by age 74 . Spending profiles are shown for the US in Figure C2. Average total spending falls less than in the UK, from $\$ 750$ at age 48 to just under $\$ 500$ by age 74 .

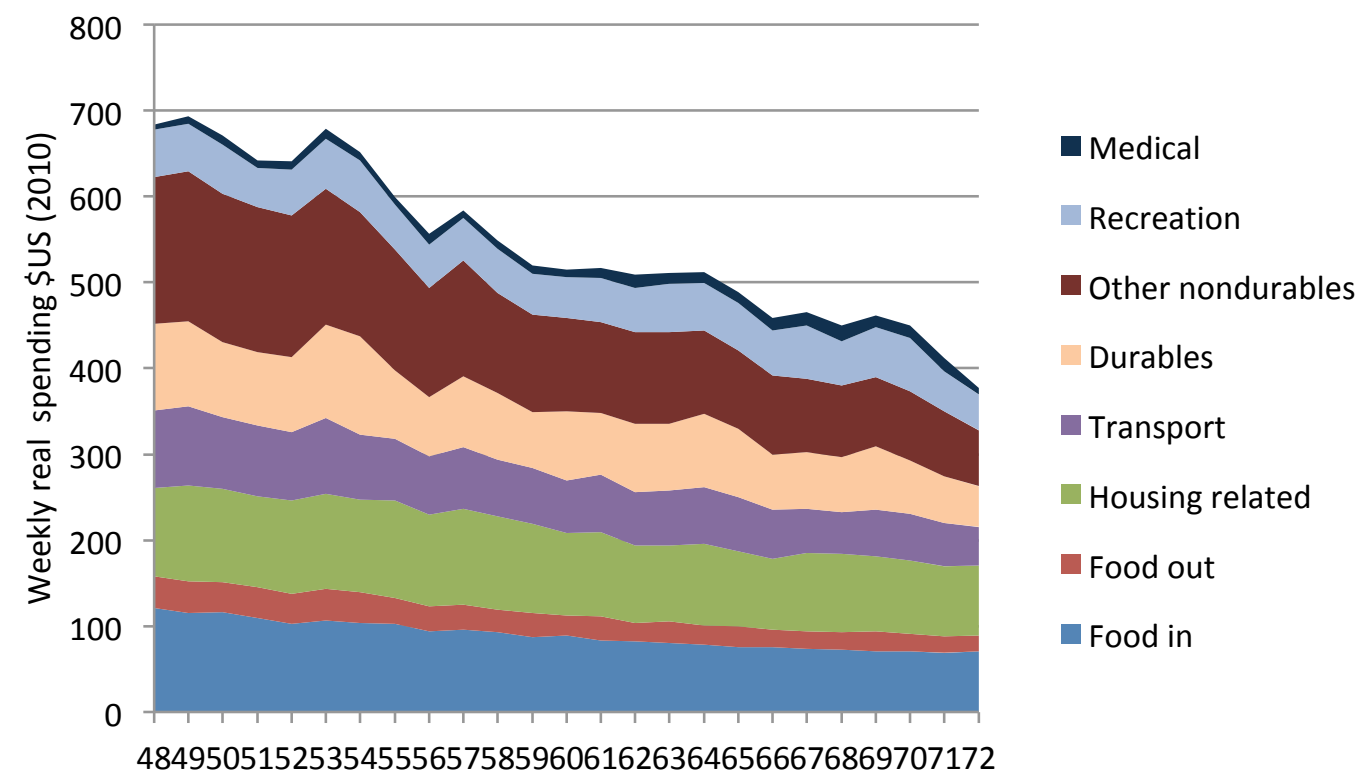

Figure C1. UK Weekly Spending on Different Categories by Age, 1933-37 Cohort

Note: Authors' calculations using BLS Consumer Expenditure Survey 1984-2010 and ONS Living Costs and Food Survey 1984-2010. Values are in US\$ (2010). 


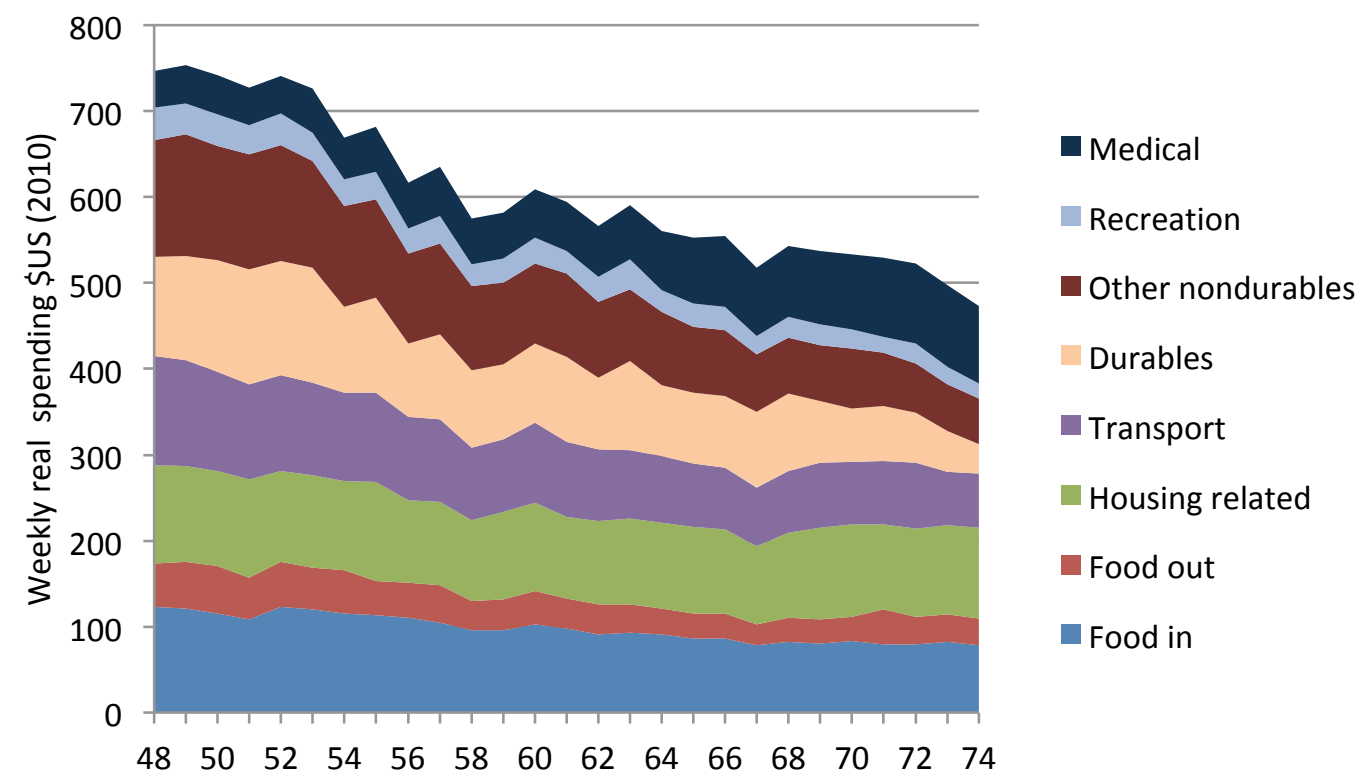

Figure C2. US Weekly Spending on Different Categories by Age, 1933-37 Cohort

Note: Authors' calculations using BLS Consumer Expenditure Survey 1984-2010 and ONS Living Costs and Food Survey 1984-2010. Values are in US\$ (2010).

There is some difference in spending patterns in the two countries. For instance, we see that, at all ages, UK households tend to spend more on recreation than American households. However, it is clear that the primary reason for the faster decline in total expenditure is the growth in medical expenditures in the US, which increase from $\$ 42$ per week at age 48 to $\$ 91$ by age 74 . In the UK, medical spending at age 48 increases from $\$ 7$ to $\$ 12$ over the same period.

\section{Appendix D: Coverage of Household Surveys}

Comparisons of both the LCFS and the CEX to the aggregate National Income and Product Accounts (NIPA) in the respective countries have highlighted the possibility of increasing measurement error over time in the two surveys. It is now well-documented that coverage rates (the proportion of consumer expenditure in the national accounts that is accounted for by the household surveys) have been declining in both the US and UK (see for example Passero et al. (2015) and Attanasio et al. (2006)). This potentially has consequences for our estimates of consumption growth. In this appendix we compare trends in coverage rates for the two countries to understand better what the implications of this might be.

Any comparison of national account and survey data must take into account the fact that the two sources of information measure different spending concepts. For example, the 
two sources cover different populations. Both the LCFS and the CEX surveys exclude foreign residents and those in institutional residences whose spending is included in NIPA. In addition, some items of spending that may be thought of as taxes are included as expenditures in surveys but are counted as transfers rather than expenditures in the NIPA. Finally, there are items for which the definitions of spending differ. For example, the NIPA impute rental costs to owner-occupiers while not including the outgoings on for example mortgage interest payments. In the US spending on healthcare made on behalf of households by employers and the government (including the Medicare and Medicaid programs) are also counted as household spending in the NIPA but are not counted in the CEX. Many of these measurement differences might plausibly be thought to have been increasing over time, perhaps differentially so in our two countries.

In what follows, we calculate coverage rates after first making adjustments to both our survey data and to the NIPA to make them more comparable. We start by removing spending by non-profit institutions on households' behalf from the personal consumption expenditures in both the UK and the US. We then exclude spending on imputed rent to owner-occupiers in the NIPA. In our surveys we remove the costs of mortgage interest, vehicle licensing costs, property taxes and (in the UK) TV licenses. We also show the consequences of removing health spending from both sources. ${ }^{3}$

Figure D.1 plots the coverage rates for total expenditure, nondurables, nondurables excluding medical expenditures and durables. The first thing to notice is that there is still evidence of a steady decline in coverage in both countries. The top left panel shows coverage rates for total spending (including medical) which decline faster in the UK than the US. ${ }^{4}$ These fall from 80 percent to 71 percent in the UK over the period 1985-2010 compared to a fall from 80 percent to 60 percent in the US. A decline in coverage of this magnitude would reduce annual spending growth as measured in surveys by around 0.5 percentage points in the UK compared to 1.2 percentage points in the US. ${ }^{5}$

\footnotetext{
${ }^{3}$ Passero et al. (2015) make more detailed adjustments to spending in the CEX and US national accounts in order to make a similar comparison. In particular they also make adjustments for the different treatment of used vehicles, financial service charges, owner-occupied shelter costs and certain insurance premiums. Without access to more disaggregated national account data we cannot make these adjustments in the UK however, and so leave the US data unadjusted in order to make the resulting coverage rates consistent. As a result the figures presented here will differ slightly from those in Passero et al.

${ }^{4}$ This differs from a similar figure (Figure 9.1) in Barrett et al. (2015). The primary difference is that medical spending is not removed from total spending here but is removed in Barrett et al.

${ }_{5}^{5}$ These figures are obtained by taking the proportional change in coverage (i.e. coverage in 2010 /coverage in 1985 ) to the power $1 / 25$. If the answer for this calculation is $1-x$, this would tell us that a reduction in the
} 

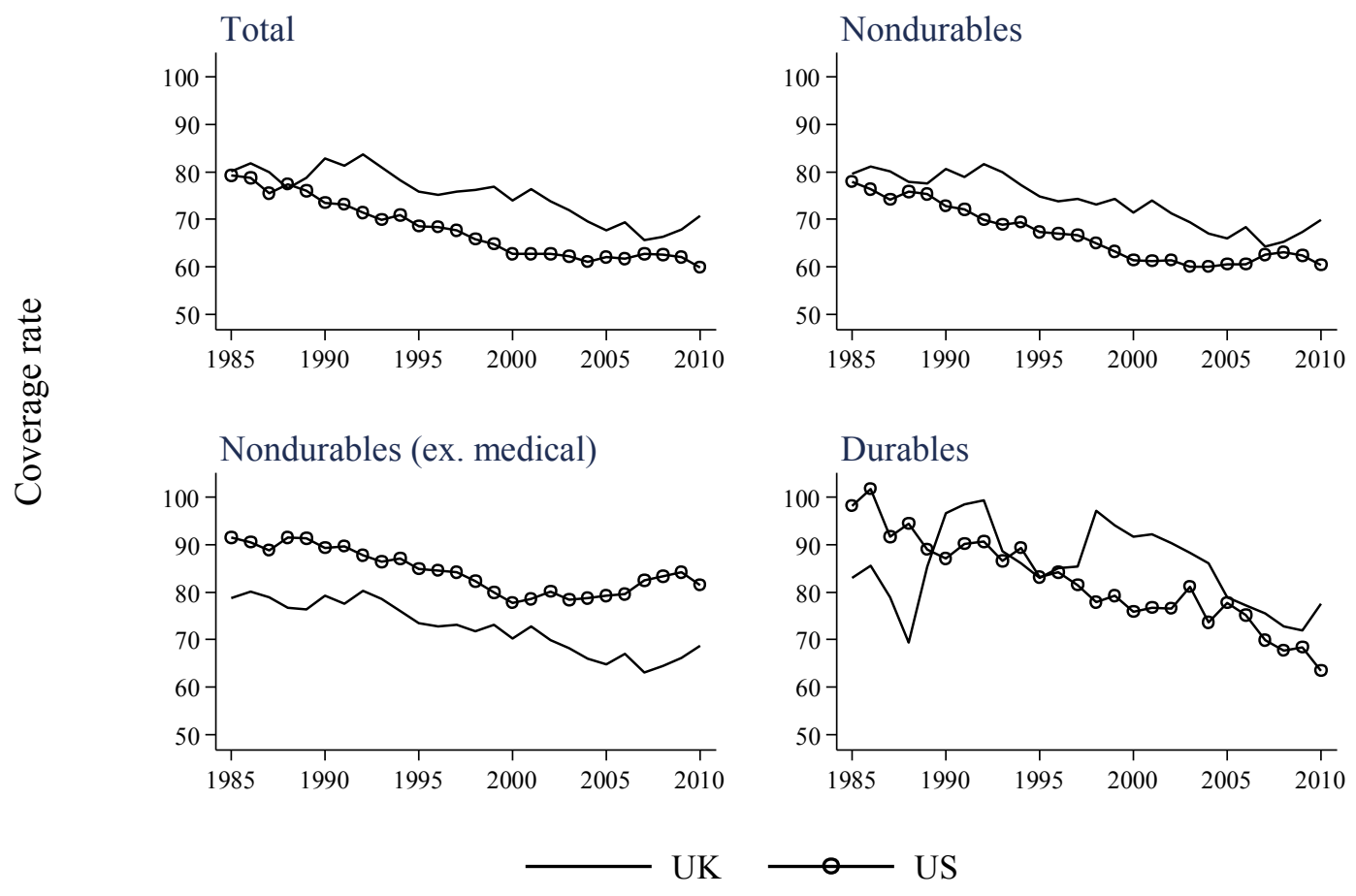

Figure D.1 Coverage Rates, 1985-2010

Note: Coverage rate is the proportion of consumer expenditure in the national accounts that is accounted for in the household surveys. Household survey data comes from the LCFS in the UK and the CEX in the US. National Income and Product Account (NIPA) data comes from the UK Office for National Statistics and the US Bureau of Economic Analysis.

The coverage rates of nondurable spending, which is the definition of spending examined in this paper, decline at similar rates. However, when we remove health spending in the bottom left panel, the picture is very different. Coverage rates are now higher in the US (where they fall from 91 percent to 82 percent) than the UK (where the fall is from 79 percent to 69 percent). The implied falls would now suggest a slightly larger understatement of spending growth in the UK (by 0.54 percentage points compared to 0.46 percentage points in the US). The difference that arises from excluding healthcare reflects the rapid growth of medical spending on US households by government and employers. As mentioned above, these expenditures are not included as household spending in the CEX survey but are included in the US NIPA. Passero et al. (2015) estimate that spending by government on behalf of households in the US increased by 271 percent from 1992 to 2010 and that this accounts for one fourth of the growth in the gap between the coverage of the CEX survey and 
NIPA consumption spending. An additional proportion is likely to be explained by growth in the proportion of health costs paid by employers. In the UK spending on the NHS is not attributed to households in the national accounts in the same way, and employer coverage is much less widespread. As a result, excluding health spending has a much smaller effect on coverage rates in the $\mathrm{UK}$.

Durable spending in our household surveys has higher rates of coverage in both countries. The CEX accounted for roughly 100 percent of the durable spending in the national accounts by our measure in the US in 1985. This fell to just 63 percent in 2010. In the UK the decline was from 83 percent to 77 percent over the same period. 
Appendix E: Consumption Growth Regressions

Table E1: Changes in Log Nondurable Expenditure

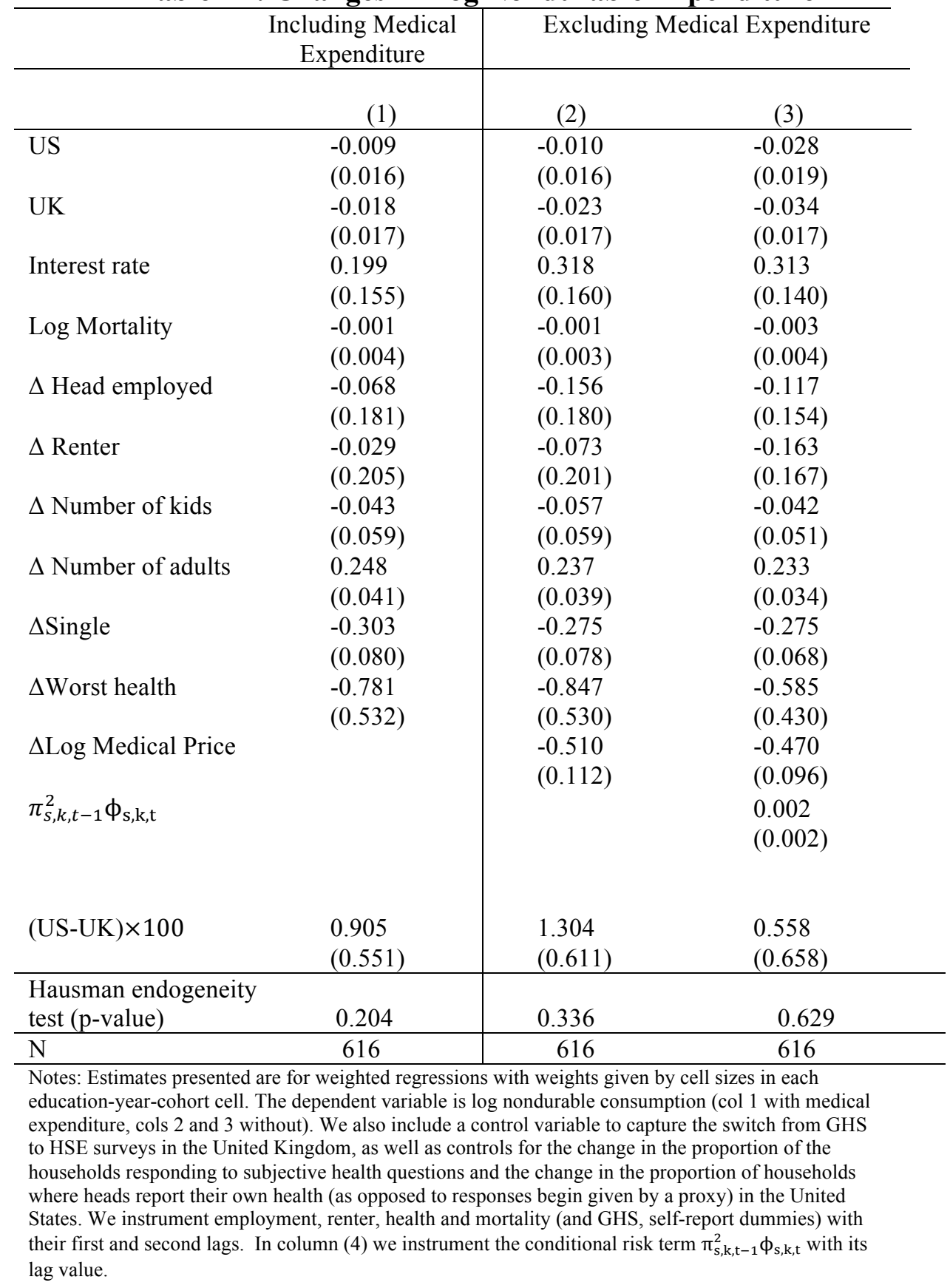




\section{REFERENCES}

Attanasio, Orazio P., Erich Battistin, and Andrew Leicester. 2006. "From Micro to Macro, from Poor to Rich: Consumption and Income in the UK and the US," Working Paper, University College London.

Banks, James, Richard Blundell, and Arthur Lewbel. 1997. "Quadratic Engel Curves and Consumer Demand." Review of Economics and Statistics 79: 527-39.

Barrett, Garry, Peter Levell and Kevin Milligan, 2015“A Comparison of Micro and Macro Expenditure Measures Across Countries Using Differing Survey Methods.” in Christopher Carroll, Thomas F.Crossley and John Sabelhaus, Eds. Improving the Measurement of Consumer Expenditures, Studies in Income and Wealth, Volume 74. Chicago: University of Chicago Press,

Deaton, Angus, and John Muellbauer. 1980. “An Almost Ideal Demand System." American Economic Review 70: 312-26.

Passero, William, Thesia Garner, and Clinton McCully, 2015 "Understanding the Relationship: CE Survey and PCE," in Christopher Carroll, Thomas F.Crossley and John Sabelhaus, Eds., Improving the Measurement of Consumer Expenditures, Studies in Income and Wealth, Volume 74. Chicago: University of Chicago Press.

Pollak, Robert A., 1969. "Conditional Demand Functions and Consumption Theory." The Quarterly Journal of Economics 83(1): 60-78. 